\title{
総説 \\ 鉱物・岩石組織から探る惑星の進化過程

\author{
The evolution process of planets explored from the texture \\ of minerals and rocks
}

\author{
佐伯 和人 (Kazuto S $\mathrm{AIKI})^{*}$
}

\begin{abstract}
Study of rock texture will surely make a breakthrough in the elucidation of the evolution process of planets. This report presents two examples showing methodologies for the study of rock texture in planetary materials. The first example is the study of pallasites. Rounded texture of olivine grains was reproduced through annealing experiments and rounding kinetics was characterized. The result shows that small scale rounding of olivine in pallasites such as Eagle Station requires a rapid cooling after olivine-metal mixing. The second example is the study of polymict eucrites. The results from detailed observation of their texture show the individual origin of pyroxene fragments and suggest that the polymict breccias were generated by gathering locally ordinary eucrites and cumulate eucrites. In future planetary exploration, observation of rock texture will serve as indispensable technology.
\end{abstract}

Keywords: Texture, Pallasite, Eucrite, The moon, Asteroid, Evolution process

\section{I.はじめに}

岩石組織の研究は, 組織の定量化や解釈が複雑である ため, 敬遠されがちである。しかし, 組織は, 岩石の形成 史を雄弁に物語っている特徵であり，さまざまな切り口で 取り組むことが可能である。本稿では,惑星科学分野で著 者が行った研究例を中心に, 岩石組織を読み解く戦略の一 例を示したい。

\section{II. 惑星の初期進化研究の意義と岩石組織という切り口} 46 億年前に太陽系星雲ガスの凝縮物が集積して微惑星 ができ,さらに微惑星が衝突合体して天体が形成した (Wetherill, 1989 等)。ここで天体とは, 惑星・小惑星・衛 星のことをいう。半径数百 $\mathrm{km}$ 以上のサイズを獲得した天 体は, 集積エネルギー, 放射性元素の壞変エネルギー, 中 心核の形成に伴う位置エネルギーや潜熱の解放により，大 部分が溶融し, 層分化し, あらたな物質の多樣性を持つに 至った (Solomon, 1979 等)。これが地球型惑星の進化であ る。地球がどうやって進化したかを知る上でも，他の天体 との比較は大変重要である。物理学や化学の研究手法は, 反復可能な観察や実験が可能な現象の解明には大変効果 的であるが, 地球の形成のように歴史上一度しか起こって いない現象の解明には, 単純には適用できない。地球の進
化は, 数百万年, 場合によっては数億年かかるような現象 の集大成であるため，部分的にも再現実験や反復実験をす る事は困難である。しかし，類似した材料がほとんど同じ 時期に集積し，兴の後の進化が樣々に異なる太陽系の兄弟 の天体か数多くある。これら複数の他天体の構造を比較 することは,パラメータを変えて惑星形成実験をした生成 物を調べるようなもので, 地球谷のものや, 天体形成とい うプロセス谷のものを理解するための重要な材料となる。 本稿で取り上げる隕石は,かつて表面が全溶融して地款や マントル等の層状構造に分離した小惑星が,崩壊してでき た破片だと考えられている。これらの隕石には分化した 天体の表層から中心付近に至るまでの各層が含まれてい るはずである。従って隕石は天体地款の垂直構造進化の 過程を探るための鍵となる物質と言える。

天体の進化はリモートセンシングデータの解䣋や，隕 石やリターンサンプル等の試料の分析結果を元に，物理モ デルを組み立てることでだんだんと明らかになってきた。 岩石組織研究の重要性は,進化モデルに冷却速度の具体的 な情報を付加できること。得られたサンプルの起源を明 らかにし, 兴のサンプルの持つ化学組成に真の意味を与え ること。物理的混合や変質など岩石が形成後にたどって きた変化の歴史を読み解くことができること，等である。 一言で言えば，状況を知る最大の情報源であるということ

(平成 16 年 10 月 8 日受付、平成 17 年 10 月 11 日受理)

* 大阪大学大学院理学研究科宇宙地球科学専攻, 干 560-0043 大阪府豊中市待兼山町 1-1

* Department of Earth and Space Science, Graduate School of Science, Osaka University, 1 - 1 Machikaneyama, Toyonaka 560-0043,

Japan E-mail: ksaiki@ess.sci.osaka-u.ac.jp 
である。

\section{III. パラサイト隕石の謎}

パラサイト隕石は , 鉄ニッケル合金の中にカンラン石 が包含される特異な岩石組織を持っている (Fig. 1)。パラ サイトを薄切りにすると，あたかもステンドグラスのよう な美しさである。比重の大きく異なる二つの物質がなぜ 分離せずに共存しているのであろうか。どのような場所 で，またどのような条件下でこの組織が形成されたのか は,大きな謎となっている。パラサイトの形成過程を知る ことは,惑星の核マントル存在形態や核マントル分離プロ セスを知る鍵になるかも知れない。まず,パラサイトの起 源についての諸説を紹介した後,組織に着目した研究を紹 介する。

1. パラサイト隕石の起源

金属鉄中の微量元素や少量元素の研究によりパラサイ 卜隕石はメイングループとイーグルステーショングルー プの二つのグループに分けられる (Scott, 1977a)。これら

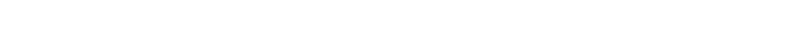
られている。Boesenberg ら (1995) は酸素同位体比の証拠 から三つ目のパラサイトのグループ: 輝石パラサイトのグ ループを報告した。このパラサイトは 86 体積 \% の金属鉄 と, 球化した, もしくはほほ球化したカンラン石, 斜方輝 石, クロム鉄鉱, 弚してウィトロッカイトからなってい る。パラサイト隕石形成には大きく分けて $2 つ$ つ説があ る。一つは一次生成説で, カンラン石と金属が混ざった岩 石組織は, 生成時の一次特徵であるという考え方である (Buseck, 1977; Wood, 1978; Takahashi, 1983; Greenberg and Chapman, 1984 等)。もう一つの説は二次生成説 (Scott, 1977b; Ulff-Møller et al., 1998; Wasson et al., 1999 等) で天 体衝突によって，マントル下部のカンラン石層が破砕し て,乥こに溶融金属核が混合したとするものである。樣々 なモデルをもう少し詳しく紹介する。

2. 火成集積物としてのパラサイト

このモデルでは, カンラン石とメタルの混合組織は一 次特徵である。Greenberg and Chapman (1984)によれば， 母天体は直径 50-100 km くらいの小さな分化した天体で あった。最初に天体が完全に溶融して金属鉄核を形成し た。乥して, 溶融した珪酸塩マグマの中からカンラン石が 晶出して, 沈降し, 密にパッキングされた集積層を形成し た。集積層下部は上部のカンラン石の重みによって押し 付けられ，カンラン石層の $10 \%$ ほどが核にめり込んだ。 カンラン石粒界は融けた金属鉄で満たされ,パラサイト状 岩石組織を持つにいたつた。Takahashi (1983) はもう少し 異なったモデルを提唱した。关れによれば,パラサイトは 部分溶融した母天体中で, メルトか珪酸塩層から完全に分 離できなかった結果生じたものとされる。

3. カンラン石とメルトの巨大衝突

Scott (1977b) によれば，コンドライト的な母天体か滆蚆 て分化して ,まず金属鉄コアと珪酸塩マントルが完全に分
離した。光の後, ダナイト的下部マントルか断片化し, 光 の角レキ岩化したダナイトの中に融けたメタルが貫入し た。断片化と混合は巨大衝突の際に同時に起こったであ ろうと推定している。

4. パラサイトの冷却速度

パラサイト母天体のサイズは今日でも決着がついてい ない。Buseck and Goldstein (1969) は鉄ニッケル合金が ニッケル含有量の異なる二つの相に離溶してできる Widmanstatten 構造の $\mathrm{Fe}, \mathrm{Ni}$ の拡散プロファイルから $700^{\circ} \mathrm{C}$ から $300{ }^{\circ} \mathrm{C}$ までの間は 100 万年あたりおよ光 0.5 $2{ }^{\circ} \mathrm{C}$ の速度で朎却したと推定した。しかし，後に Narayan and Goldstein (1983), Yang et al. (1997) では ,この值は過小 評価であったと結論し，後者によると 100 万年あたり 2 〜 $5{ }^{\circ} \mathrm{C}$ 程度としている。Buseck and Goldstein (1969) の遅い 冷却速度は，何百 $\mathrm{km}$ もの直径をもつ母天体の深部でパラ サイトができるとするモデルの最も強力な証拠であった。 新しい冷却速度による見積もりでは,パラサイト母天体の 直径は $50 \mathrm{~km}$ にまで小さくなる (Greenberg and Chapman, 1984)。 Miyamoto and Takeda $(1993,1996)$ と Miyamoto (1997) ではカンラン石中の $\mathrm{FeO}, \mathrm{MgO}, \mathrm{CaO}$ の濃集プロ ファイルを測定することで, パラサイトの温度履歴を調へ ることを試み, $1100{ }^{\circ} \mathrm{C}$ から $600{ }^{\circ} \mathrm{C}$ のリニアクーリングで およ光 20-200 ${ }^{\circ} \mathrm{C} /$ 年という冷却速度を推測した。1 年あた り 20-200 ${ }^{\circ} \mathrm{C}$ という冷却速度は , パラサイトと同程度の熱 拡散率 $0.1 \mathrm{~cm}^{2} / \mathrm{s}$ の岩石層の下にあったとすると，数十 $\mathrm{m}$ 程度の深さに埋もれていたことを示唆している。カンラ ン石から計算された冷却速度は $1100^{\circ} \mathrm{C}$ から $600{ }^{\circ} \mathrm{C}$ といっ た高温域での推定値であり,メタルから計算される冷却速 度は $700{ }^{\circ} \mathrm{C}$ 以下の低温域での推定值であるので, メタルと カンラン石の混合直後は表面付近で急冷された後, 断熱性 の高いレゴリスで覆われたために冷却速度が遅くなると いう二段階冷却モデルも考えられる (Miyamoto, 1997; Taylor et al., 1987)。化学ゾーニングプロファイルのモデリ ングはデリケートであり,化学ゾーニングが発達した温度 の推測に大きく推定冷却速度は左右される。また, 試料を 覆っていたものか熱伝導率の高い岩石か, 熱伝導率の低い 圧密の程度の低いレゴリスかによっで冷却速度と埋没深 度の関係も大きく変わるので, 冷却環境を特定するには, さらなる証拠集めが必要である。

5. パラサイト組織再現実験

パラサイトの岩石組織は, カンラン石の形により 2 種類 に大別される。多くのパラサイトは丸くなったカンラン 石を持つが(Fig. 1a)，イーグルステーションのように角 張った形を持つものもある (Fig. 1b)。角張ったものも,さ らに拡大してみると，角の部分がわずかに丸くなっている ことか観察される。このように角が丸くなる現象は,カン ラン石が鉄ニッケル金属中で高温に保たれたためにおこ ると考えられている (Buseck, 1977; Scott, 1977b)。Scott (1977b) のモデルでは, カンラン石一金属間の岩石組織の バリェーションは,巨大衝突による破砕混合後のアニーリ 
a

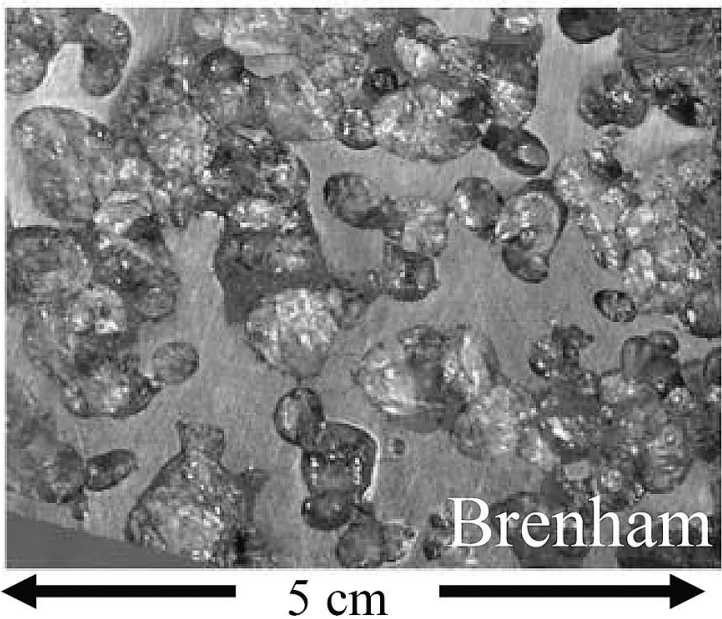

b

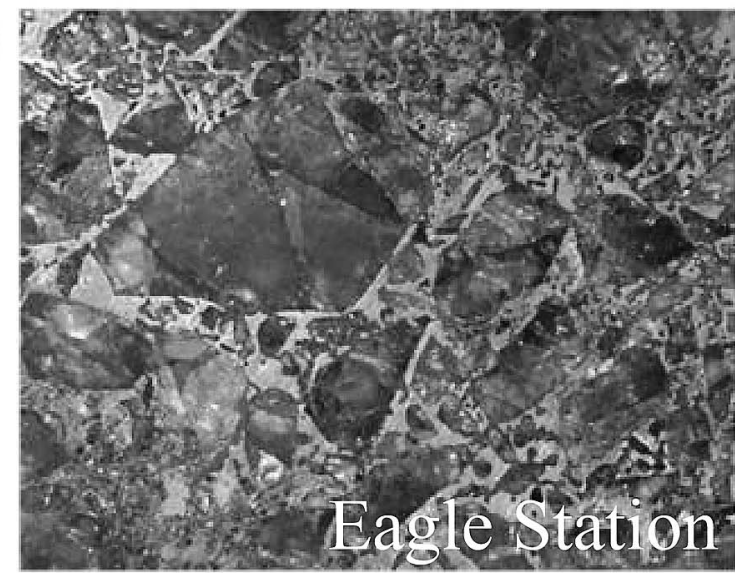

Fig. 1. Photographs of (a) Brenham pallasite with rounded olivines, and (b) Eagle Station pallasite with angular olivines.

ングの程度の違いを表している。もしカンラン石・金属の 混合物が急速に冷え固まったとしたらカンラン石は角 張ったままで残り，角張った粒の角のみがわずかに丸みを 帯びるという訳である。

著者は丸くなる速度を調べることでパラサイトの熱史 が明らかになるのではないかと考えた。乥こで,フランス のブレイズパスカル大学実験岩石学研究室で, パラサイト の組織再現実験を行った (Saiki et al., 2003)。カンラン石の 粉 $(\mathrm{Mg} /(\mathrm{Mg}+\mathrm{Fe}) \mathrm{mol}$ ratio $=0.91$, 粒径 $20 \mu \mathrm{m}$ 以下 $)$ と $\mathrm{Fe}$, $\mathrm{Ni}$ パウダーを $1: 5$ の体積比で昆ぜ，ピストンシリンダ装 置を使ってアニーリングをした。結果の一部の走査電子 顕微鏡 (SEM) 写真を Figure 2 に示す。

$1400{ }^{\circ} \mathrm{C}, 4$ 時間のカンラン石の形状は, 粉砕したままの 初期形状とほぼ同じである。これを $1400{ }^{\circ} \mathrm{C}, 1$ 週間かける ことで, Figure 2c のように, カンラン石か球化したパラサ イトに類似した岩石組織を再現する事に成功した。なぜ， カンラン石も FeNi 合金も溶融しない温度なのに固相のま ま球に変形したのか? 弚れは,拡散クリープという現象で 説明できる。「粒子の界面エネルギーを最低とするように 極小表面積の球に近づいた」と解釈できる。別の表現をす ると，「角張った曲率の高い曲面にいる分子が曲率の低い
周辺に移る事で減る界面面積の分，エネルギー的に得なの で, 兴の化学ポテンシャルを駆動力として拡散フラックス が生じた」と言うこともできる。曲率とは曲面に内接する 球の半径の逆数である。

アナログ実験で難しいのは, 現象の再現以上に , 実験室 の現象と自然現象との対応をつける部分である。何百万 年もかかって起きるような現象がたった 1 週間で起きたの は微小スケールの実験をしたからである。実際のパラサ イトカンラン石のサイズにもどした結果を考えるために は, 現象のモデル化が不可欠である。乥こで, 粒界拡散を 仮定して次のようなモデルを作った。カンラン石表面の 微小セルに流入する分子数を $\mathrm{N}$, 有効拡散層厚を $\delta$, カン ラン石表面か盛り上がる高さを $h$ とすると ,Figure 3 の $\Delta h$ の形状変化を起こすのに必要な時間 $\Delta t$ は拡散の式を变形 していくことで以下のように表すことができる。

$$
\Delta t=-\frac{k T}{D \gamma \Omega \delta}\left[\frac{\partial^{2} \kappa_{x}}{\partial x^{2}}+\frac{\partial^{2} \kappa_{y}}{\partial y^{2}}\right]
$$

ここで, $D$ はカンラン石分子の拡散定数,$k$ はボルツマ ン定数, $T$ は絶対温度,$\kappa$ は曲率 (カンラン石粒表面の凸面 の曲率を正，凹面の曲率を負と定義),$\gamma$ は単位面積あたり の界面エネルギー, $\Omega$ はカンラン石分子の体積である。こ のモデルから, 粒界拡散の場合は, 形状変化の時間は粒子 サイズの 4 乗に比例することか推定される。また，体積拡 散の場合は拡散有効層厚もサイズ依存があると考えるこ とで, 形状変化時間は粒子サイズの 3 乗に比例することが 推定される。このモデルは, 冶金の分野で古くから研究が 進んでいる拡散クリープのモデルと駆動力こ关違うもの の結果的にほとんど同じ形となる。体積拡散は NabarroHerring Creep (Herring, 1950)，粒界拡散は Coble Creep (Coble, 1963) と呼ばれている。どちらの樣式の拡散が支 配的であるかで, 現象の速度が大きく変化する。光して どちらが支配的かを知るためには高温保持時間と組織の 変化量とを定量的に論じる必要がある。

通常粒の丸さの評価には, 「周囲長 $\div$ 粒と同じ面積を 持つ円の半径」という值が使われる。しかし，このパラ メータは角が少し取れるような微妙な変化には鈍感であ るし, 初期形状の影響が大きすきて使えない。粒の重心に 原点を取って粒境界までの動径の長さ変化を関数化して フーリ工解析するという手法もあるが, 拡散クリープの現 象と直接対応するようなデータにはならなかった。試行 錯誤の結果 ,一つの使えるソフトウェアが完成した。乥れ は粒周辺の形状をスプライン関数でフィッティングした 後, 形状を曲率分布で表す方法である (Saiki, 1997)。この 手法は, ある程度丸くなった曲線の解析には大変効果が あった。地層から古水理条件を読み取るためのリップル 形態の解析 (井出ら，1999)，ママイロナイト中の再結晶組織 の解析 (Nishikawa et al., 2003) 等, 他の研究者の曲線構造 の解析にも役立ててもらつた。しかしながら，曲率解析は ある程度丸くなったものの解析には威力を発揮するが,角 


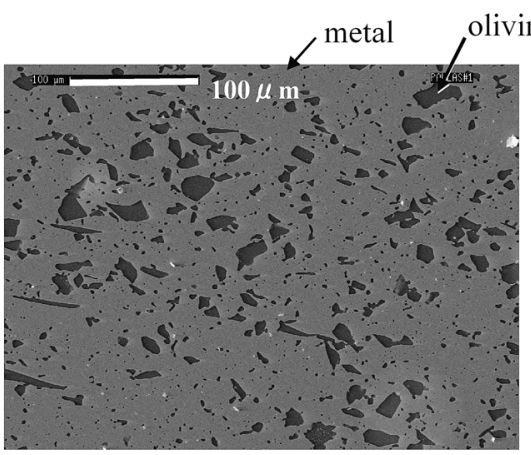

(a) $1400{ }^{\circ} \mathrm{C} 4$ hours

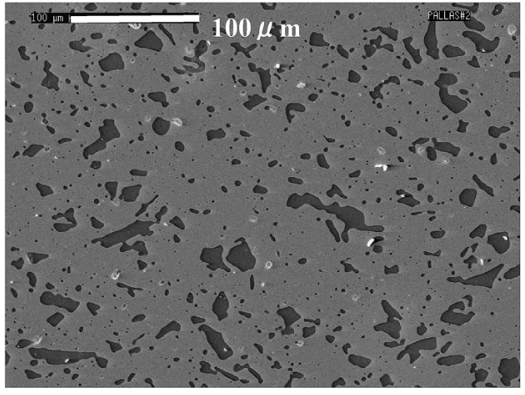

(b) $1400{ }^{\circ} \mathrm{C} 27$ hours

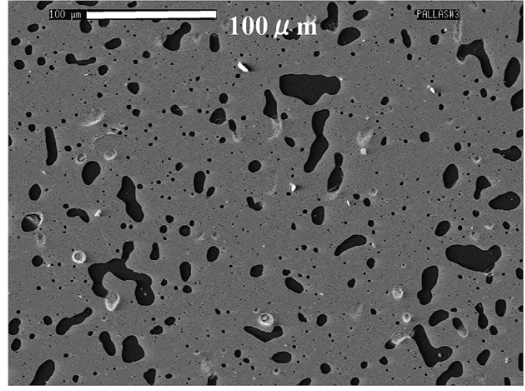

(c) $1400{ }^{\circ} \mathrm{C} 7$ days

Fig. 2. Secondary electron images of polished sections of the run products at $1400{ }^{\circ} \mathrm{C}$. Run duration is (a) 4 hours, (b) 27 hours, and (c) 7 days. Scale bars $=100 \mu \mathrm{m}$.

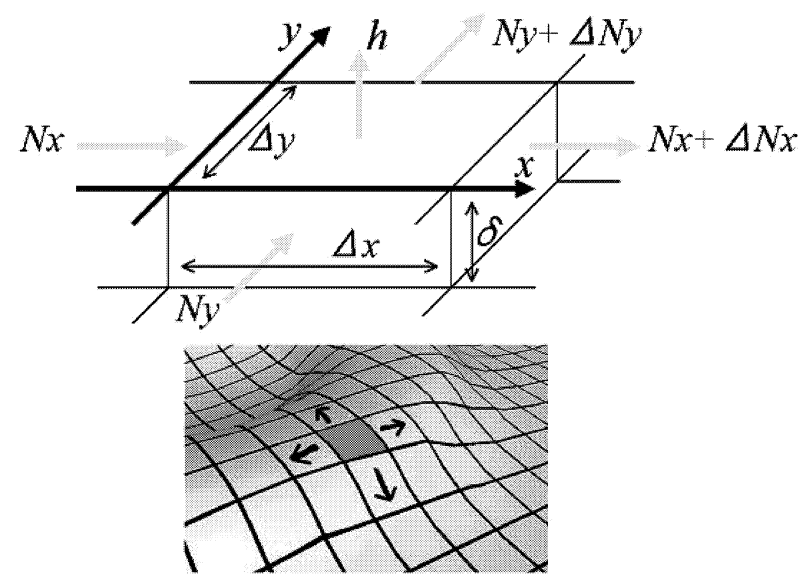

Fig. 3. Sketches showing the model for matter transport near the surface of olivine grains: gradients in chemical potential along the olivine-metal interface drive a flux of olivine molecules from regions of larger curvature, such as the hump in the bottom sketch, to regions of smaller curvature.

がほんの少し丸くなるような初期の変化を検出するには 不十分であった。关れは,スプライン関数にフィットする 過程で, 細かい起伏の情報が失われるからである。さらに 試行錯誤を重ね，全く新しい解析方法を考えついた。弚れ は,観測の尺度を変える方法である。人間の眼は細かなと ころに注目するときは細かな尺度で測定し,形全体を把握 する時は大雑把な尺度で測定をしている。光の尺度の自 動的な変化のおかげで,粒の角が少し取れるような変化か ら,粒の形全体の変化まで,一目て総合的に解釈できるの であろう。乥こで, ソフト的に尺度を変える事を考えた。 これは,フラクタル解析の手法に少し似ている。 Gaussian-Diffusion-Resample Method (GDR 法) と名付けた この方法の詳細を解説する (Fig. 4)。まず粒子形状を輝度 0 (背景) と輝度 255 (粒)の 2 值画像にし (a) , 次にガウス ぼかしをかける (b)。ガウスぼかしというのは, 輝度をガ ウス分布状に拡散させる処理で, ガウス分布の $1 \sigma$ の幅を 変える事で, 少し拡散させることも, 広範囲に拡散させる こともできる (Fig. 5 は 1 次元の例。実際の画像処理には
2 次元ガウス関数が使われる)。光して拡散した画像を再 び2 值化する (c) のであるが, 弚のときは, 元の粒と面積 が同じになるように, 輝度の閾值を計算して決める。乥う すると,ガウス分布のぼかし幅に応じた角のとれた画像を 作ることができる。最後に元の粒から角が取れた粒を引 き算し，減った角の部分の面積を測定することで, 球化の 度合いを判定する (d)。つまり，角張った物質はガウスほ かしの半径が小さくても欠落するピクセルがあり，ある程 度球化したものは,ガウスぼかしの半径を大きくしないと 欠落するピクセルが出てこないという理屈である。こう して, ガウスぼかし半径と拡散・再二值化によって欠落し たピクセルをグラフにする事で, 異なる実験生成物画像相 互て球化の度合いの微妙な変化を定量的に比較できるよ うになった。画像解析ソフトウエア NIH-Image のマクロ 言語て記述された解析手続きのソースは Saiki et al. (2003) に記述されている。人間の感覚ではわかりにくいわずか な球化の差しかない場合も，この解析法を使うと，アニー リング時間に応じた差を明確に見分けることができるよ うになった。アニーリング温度・時間と組織の観察倍率を 変えた多数の球化度データの比較の結果, 時間はサイズの 3 乗のスケールを持っている事がわかり，支配的な拡散プ ロセスは体積拡散であることか推定された。

この結果から実際の小惑星で起こった出来事を推定す る。球化したパラサイト隕石と球化していないもの (実は 角がほんの少しだけ球化している)を比べると，1300〜 $1400{ }^{\circ} \mathrm{C}$ 前後の状態では，丸いカンラン石の形成には数百 万年から数千万年かかるのに対して, 角張ったカンラン石 の寿命は，長くても 100 年前後と計算できる。つまり角 張ったカンラン石は核マントル境界のような冷却速度の 遅い場所では存在できないという事になる。さらに,カン ラン石と $\mathrm{FeNi}$ 合金の混合の時には少なからずメルトが存 在していたはずであるが, メルトが存在すると拡散速度は 何桁も加速すると考えられので，ますます角張ったカンラ ン石は惑星表層で朎却しなくてはできないという結論に 達する。パラサイト全てが弚うだとは言えないが, 少なく とも角張ったカンラン石を含むものは, 天体衝突によって 
(a)

(b)

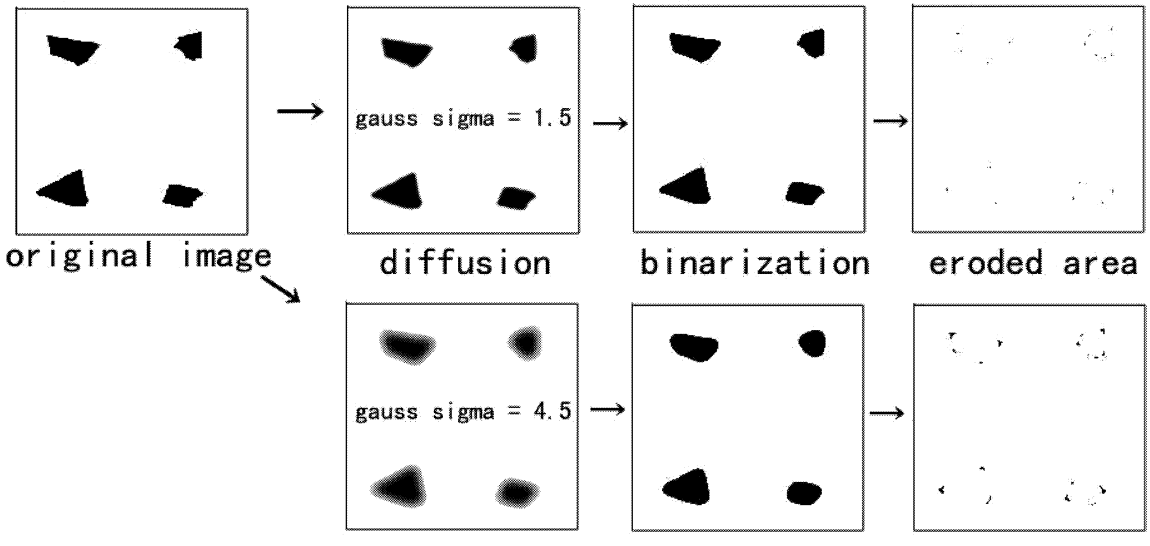

Fig. 4. The Gaussian Diffusion-Resample method. (a) Initial image constructed by picking up a certain regular number of grains from the binarized secondary electron image. For clarity, only four grains are shown. (b) Image filtered by Gaussian diffusion. (c) Rebinarized image; the total area of grains in the initial image and in the rebinarized image are equal. (d) Resultant image obtained by subtracting (c) from (a). The subtraction in (d) yields for each grain a few islands of residual pixels that correspond to the angular portions of the olivine grains. The aperture of the Gaussian diffusion filter is 1.5 pixels in the upper row and 4.5 pixels is the lower row.

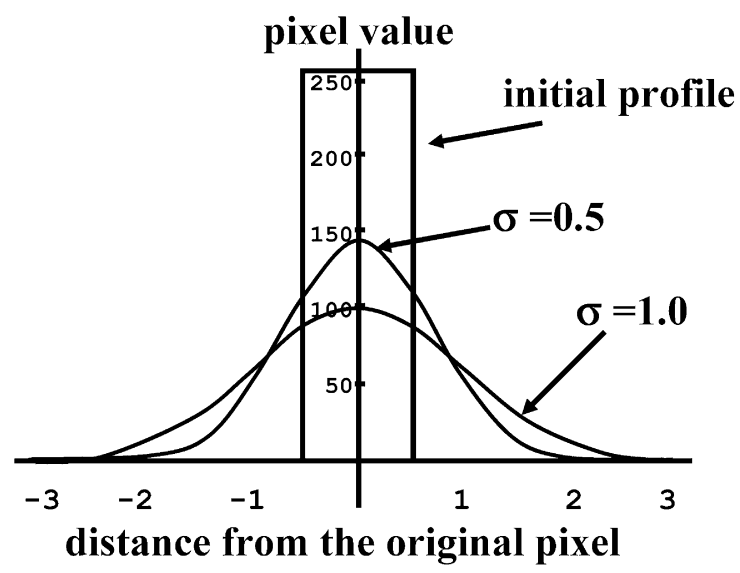

Fig. 5. Sketch showing one-dimensional Gaussian diffusion.

カンラン石と鉄ニッケル合金が急速に混合したのち, 天体 表層付近で急冷されたものだと推定できる。

前述のように, パラサイト隕石の冷却速度データゃ 起源を示唆する化学分析データは樣々な研究から提出さ れているが, 冷却環境が複数あるという前提のもとに, 岩 石組織での分類を行った後, 各データを再整理する必要が ある。また , 冷却速度の問題以前に, 母天体のかなりの体 積をカンラン岩層が占めていたはずであるが,カンラン岩 だけで構成された隕石が見当たらないことは大きな謎で ある。天体の核マントル分離過程には我々のまだ全く思 いついていない過程が存在するのかも知れない。

IV. ポリミクト隕石はもともとの地層の特徵を反映し ているか?

小惑星にある樣々な起源を持つ岩石が度重なる隕石衝 突による掘り起こしのために混合して再び岩石として固 化したものがある。このような多樣な起源を持つ複数種
類の岩石が混合してできた隕石をポリミクト隕石と呼ぶ。 一方, 地款やマントルが分離したと考えられる小惑星から 来た隕石にユークライトという種類のものがある。ユー クライトはパラサイト母天体の地殼を形成していたとい うモデルもあり,ユークライト母天体の構造の推定は小規 模な天体の層分離過程のメカニズム解明の鍵となる。母 天体の一つとして有力な候補は小惑星ベスタである。 のユークライトの中にもポリミクト隕石がある。ポリミ クトユークライトの中には種類の異なる岩石が複数含ま れているため,数々の地層を掘りぬいたボーリングコアを 砕いて見ているようなものである。構成岩片を細かく調 べることで,地款表層から深部までの樣々な地層を復元す ることが可能なように思われる。著者は光のような発想 で, 小惑星の地層の復元を試みた。例えば， Figure 6a の Yamato82009 隕石には化学組成や鉱物組織で分類すると， 5 種類の起源の異なる輝石が含まれている (Fig. 6a-d)。 Figure 6 では輝石に, Mg/Fe 比と離溶組織が似た輝石を含 む,ポリミクトではない隕石の頭文字をつけている。D イプは,ユークライト隕石と同じ母天体から来たと考えら れているダイオジェナイト (diogenite) 隕石という隕石種 の輝石によく似ている。 B , MC タイプは弚れ光れビンダ (Binda)，ムアカウンティ (MooreCounty) という集積岩ユー クライト隕石の輝石に , JV タイプはジュビナス (Juvinas) という普通ユークライト隕石の輝石に似ている。Zタイプ は表層ユークライト隕石の輝石に似ているが, 化学ゾー二 ング構造を持つためゾーニングの頭文字のZをタイプ名

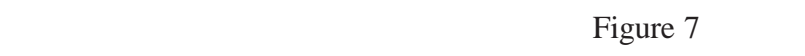
(Saiki and Takeda, 1999)。マグマ分化の一般則から考えて , $\mathrm{Mg}$ に富むものから順に固化したと推定できるが, 多くの ポリミクト隕石の観察を総合すると, 輝石の鉱物組織も光 れを裏付けている。もつとも $\mathrm{Mg} / \mathrm{Fe}$ 比の高い D タイプを 除き, 初期に晶出したものほど Ca の離溶組織が発達して 

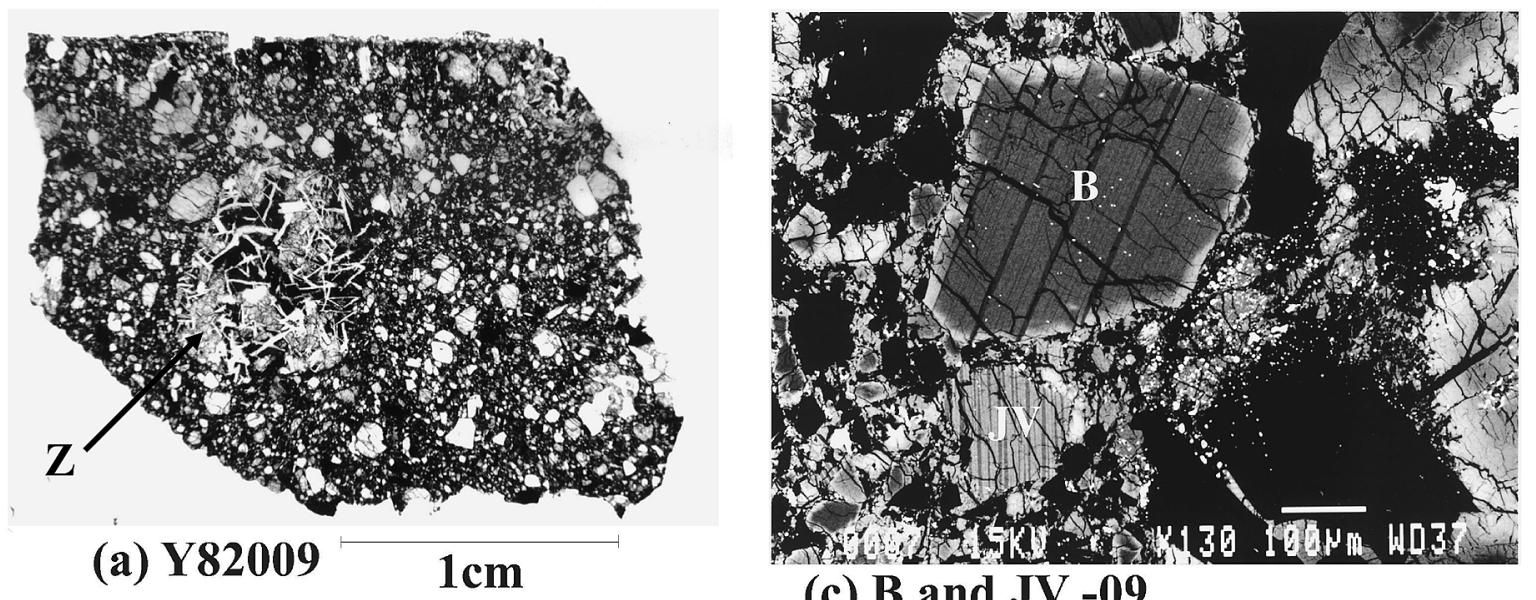

(c) B and JV -09

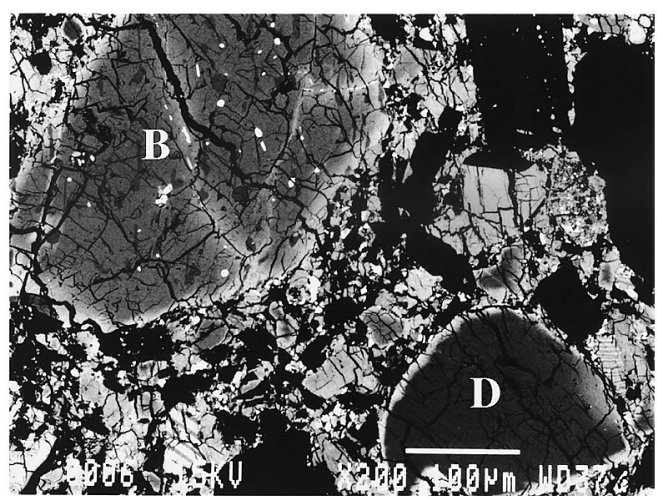

(b) B and D -09

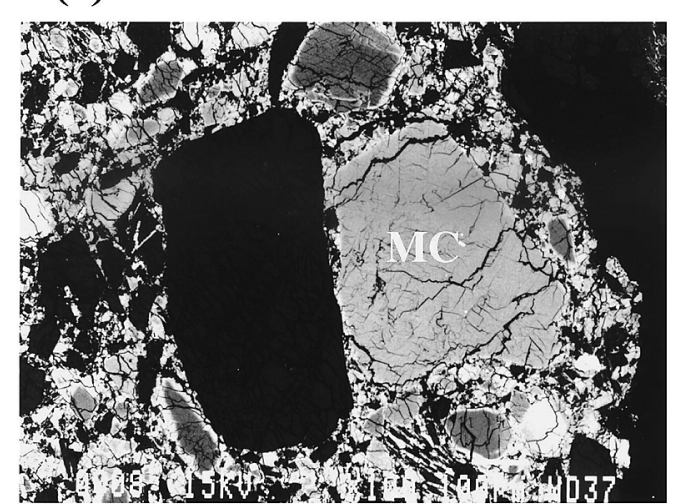

(d) MC-09

Fig. 6. Photomicrographs of Y82009. (a) plane-polarized light and (b)-(d):backscattered electron images of typical pyroxenes in Y82009. (b) D and B-type, (c) B-type pyroxene with both exsolution lamellae and Fe-enriched rim and JV-type pyroxene, (d) MC-type.

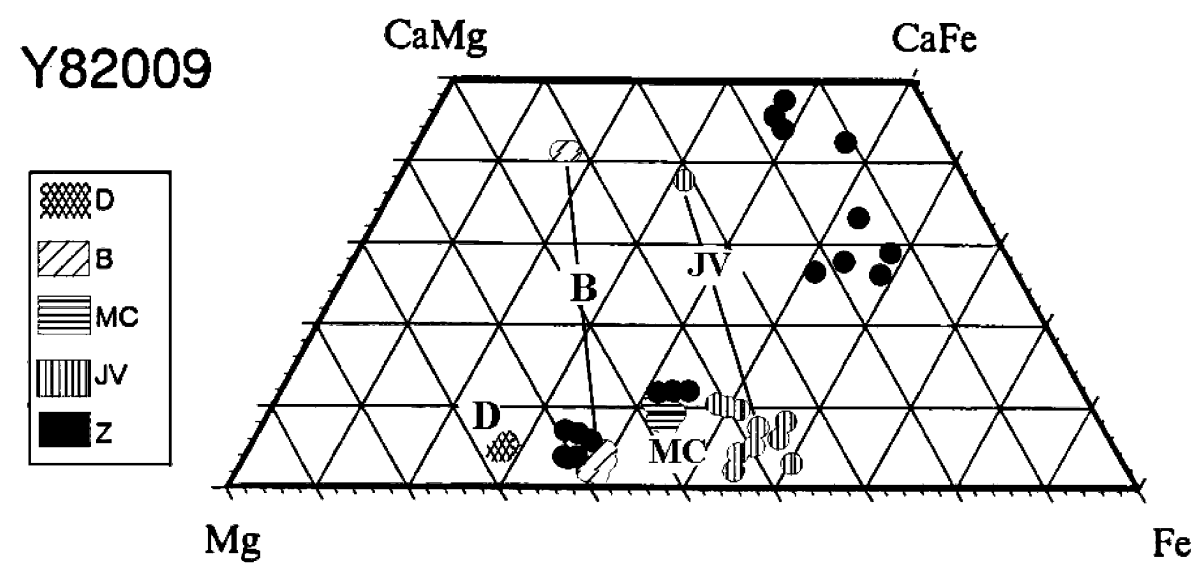

Fig. 7. Pyroxene quadrilaterals showing the distribution for each type of pyroxene in Y82009.

おり, 深部でゆっくり冷えたことを示唆している。Figure 6 では Ca に富む部分が暗い縞となっている。D タイプは $\mathrm{Ca}$ 含有量が少ないために離溶組織はできなかったと解釈 できる。また ,もつとも表層にあったと思われるZタイプ の輝石は Fe-Mg 化学ゾーニングを残しており, 晶出後に 高温環境に保持されなかった事を示唆している。鉱物組 織からだけでも含有岩片の種類を区分し，冷却環境を推定 することができる。
著者はこのようなポリミクト隕石を複数調べてユーク ライト母天体の垂直構造を推定し, 次のようなモデルを提 唱した。「JVタイプと似た輝石を持つ普通ユークライトと いう隕石と, $\mathrm{MC} や \mathrm{~B}$ タイプのような輝石を持つ集積岩 ユークライトという隕石は同じ母天体で近接して存在し ており，しかも集積岩ユークライトは集積岩といいながら も，樣々な種類のものが垂直分布している」というもので ある。しかし , 米国では , 「混合後の加熱のために元の岩 
(a) maximum fractionation

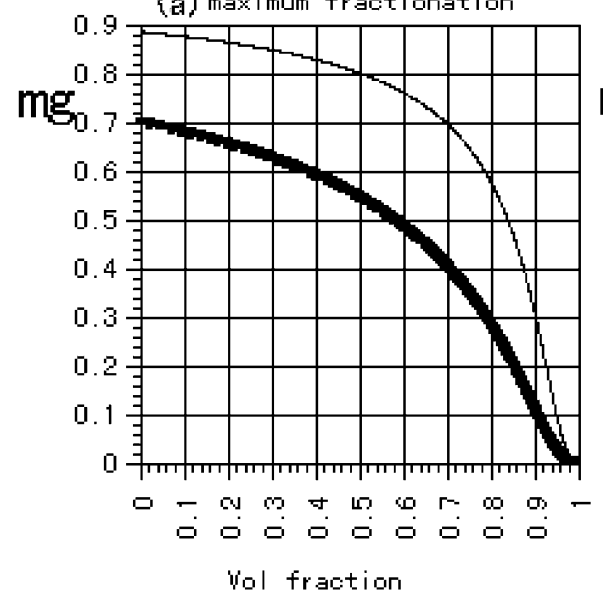

(b) 50 wolk trapped I iquid

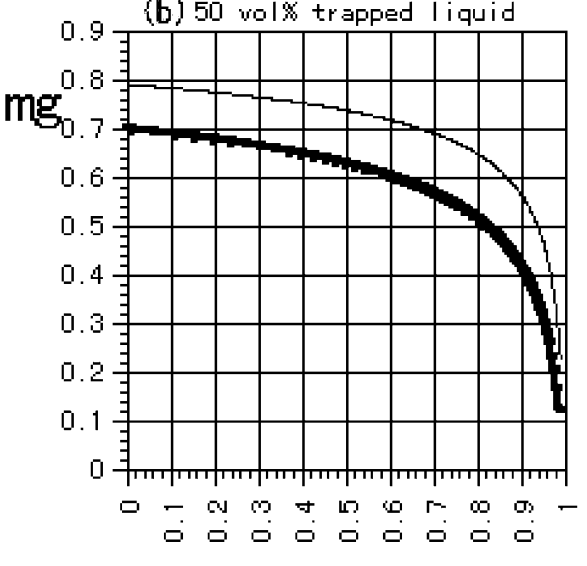

Vol fraction

Fig. 8. The liquid path and instantaneous solid path in fractional crystallization. Vertical axis is $\mathrm{mg}$ number $(=\mathrm{Mg} /(\mathrm{Mg}+\mathrm{Fe})$ atomic ratio). (a) The case of maximum fractional crystallization. (b) The case of fractional crystallization with trapped liquid. The calculation assumes trapped liquid of $50 \%$ volume fraction in cumulus.

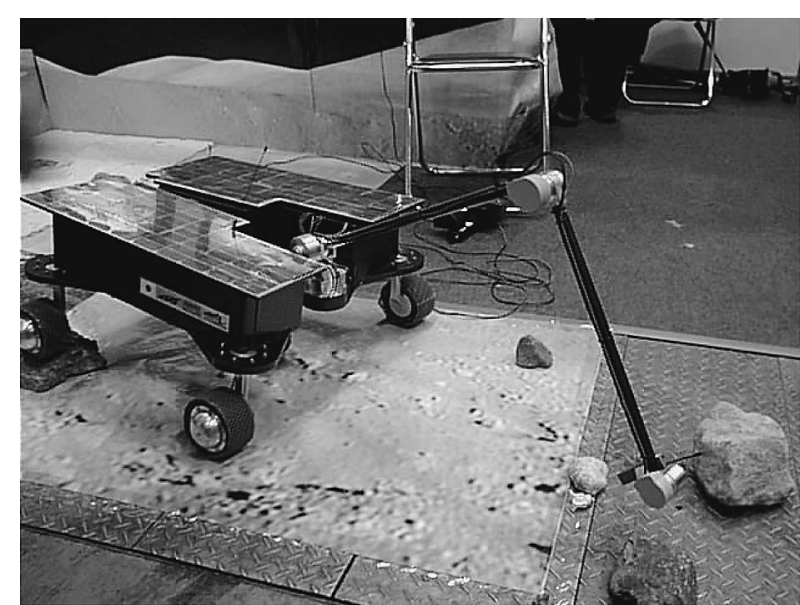

Fig. 9. Photograph of Micro-5 lunar rover.

石の化学組成は保存されない」という考えが主流であり， 著者の論文は 96 年にリジェクトされた。光こで, 著者は， 元の岩石形成時の組織と混合後の影響を分離できるよう な岩石・鉱物組織を探した。Figure 6cのBタイプ輝石に， まさに求めていた組織があった。太い離溶ラメラができ た輝石の周辺部が後方散乱電子像で明るくなっている。 これは,周辺の $\mathrm{Fe}$ に富む領域から拡散で $\mathrm{Fe}$ か輝石内に進 入してきた事の現れである。これこ弚が,混合後の均質化 現象である。離溶組織の拡散速度と, 混合後の均質化の拡 散速度を見積もった (Saiki and Takeda, 1999)。アニーリン グ温度を $1000{ }^{\circ} \mathrm{C}$ と仮定すると，離溶ラメラ形成には 280 〜 400 年かかる一方, Fe 拡散組織は 2 年でできる事がわ かった。温度が仮定である以上,絶対値にあまり意味はな いが, これだけ時間の差があるということが重要である。 この必要な時間差から， Fe の拡散はラメラ形成より後の 出来事であり, かつ, $\mathrm{Fe}$ の拡散の速度は速いので, 周辺の
$\mathrm{Fe}$ 拡散部分を除いた輝石の中心付近の Fe/Mg 比は , 少な くとも混合前に岩片か独立して存在していた状態のもの を保存していると考えて良いと結論できる。

さらにもう一っ，ユークライトには大きな謎があった。 ユークライトの中には,マグマから析出して集積したと考 えられる集積岩ユークライトと,マグマ兴のものが固結し たと考えられる普通ユークライトという隕石がある。こ れらの起源は別々に論じられるのが常であった。产の大 きな理由は，化学組成の整合性のなさであった。マグマと 乥こから晶出した結晶が集積してできた岩石には,元素分 配の制約から「固相の $\mathrm{Fe}^{2+} / \mathrm{Mg}=$ 液相の $\mathrm{Fe} / \mathrm{Mg} \times 0.30$ (主 要な苦鉄質鉱物が輝石の場合) 」という関係が成り立つ (Stolper, 1977; Grove, 1978; Longhi and Pan, 1988; Barrat et al., 2000)。すなわち, 集積した岩石はマグマよりも , 分配 係数によって決まる割合で $\mathrm{Mg}$ に富み，Mgに富む結晶を 落としたマグマはさらにFeに富むようになる。ところが， マグマから晶出したものが集積岩ユークライトで, 残液が 固まったものか普通ユークライトであると仮定して, 普通 ユークライト組成の液から $\mathrm{Fe}^{2+} / \mathrm{Mg}$ の固液分配の計算をす ると, 既知の隕石コレクションの集積岩ユークライトの多 くは $\mathrm{Fe}^{2+}$ が過剩に含まれていることとなり問題である。 一方, 普通ユークライトの存在は無視して, 多くの集積岩 ユークライトと共存する仮想マグマの $\mathrm{Fe}^{2+} / \mathrm{Mg}$ を計算する と，Feに富むマグマが大量に存在することになるが, 弚の ような Fe に富むマグマが固化したような隕石はほとんど 見られないという問題もあつた。これらの問題のために， 両者の起源を同時に論じることができなかった。ポリミ クトユークライト中に普通ユークライト的な破片と集積 岩ユークライト的な破片とがどちらも見つかることから， 著者は普通ユークライトと集積岩ユークライトは垂直分 布していると考えた。乥して,連続的につくる方法として 
集積岩の鉱物粒間にマグマがトラップされた状態で沈積 すれば，マグマの組成の割に Fe に富む集積岩をつくるこ とができると考えた。このアイデアも 96 年にリジェクト された。ところが觉の直後, トラップされた液で集積岩 ユークライト組成をつくるというアイデアを，もつと巧妙 に論じた論文が出てきた。Treiman (1997) が兴れである。 奇しくも光の査読者をやることとなった。彼は樣々な集 積岩ユークライトの希土類元素の組成リストをつくり，卜 ラップ液の混入でREEのパターンか説明できることを示 した。この論文が世に出て後, 集積岩ユークライトの化学 組成のバリエーションをつくる原因の一つはトラップ夜 の量であるという考え方が学会に浸透した。トラップ液 説の浸透と，先のポリミクト隕石が混合前の組成を保持で きるという論文を礎に,ようやく普通ユークライトと樣々 な化学組成の集積岩ユークライトを一連のマグマ分化で つくるモデルを発表することができた (Saiki et al., 2001)。 Figure 8 は, マグマと晶出した岩石が完全に分別した場合 と, 岩石にマグマが $50 \%$ 混入しながら分別した場合の固 体と液体の化学組成の変化を計算したものである。50\% 程度の混入を過程すると， $\mathrm{Fe}^{2+}$ に富む集積岩ユークライト をつくりつつ, 最後は普通ユークライト組成のところでマ グマの進化を止めることができ,ポリミクト隕石にふくま れている樣々な組成の岩石を一連のマグマ進化でつくる ことができるわけである。このモデルは論文発表はなさ れたが,樣々な種類のユークライトが同じ地域に垂直分布 しているという考え方は, 欧米の研究者にとっては，まだ まだ突飛な説と受け取られているようである。

岩石組織から得た直感的アイデアを信頼されるモデ ルとするには, 補完する証拠集めや，モデルを組み立てる 個々のアイデアの学会への浸透など, 乥れなりのステップ が必要であることが研究を通じて実感される。母天体上 の粉砕された岩片が再固結していく過程は研究例がほと んどない未開の分野であるが,岩石組織の研究がこの分野 を切り開く重要な道具となるであろう。

\section{V. 岩石組織研究の今後}

著者は岩石組織研究の新たな展開をめざしている。光 れは, 宇宙における岩石組織観察技術の開発である。現 在 ,日本は月探査計画 (SELENE) を準備中である。今回は 着陸探査ではないが,この何年か後の実現をめざしている 次期月探査計画では着陸探査の構想がある。著者は岩石 切断研磨装置の搭載を提案し, 中央大の國井康晴博士や宇 宙研の久保田孝博士の研究室で無人観測車ローバ開発 (Fig. 9) に並行して岩石研削装置の開発か淮んでいる。冷 却や切りくず排出のための水や大気がない環境で岩石を 加工するというのは大変な挑戦である。光して, 著者のと ころでは, 岩石切断面から, 地質学者か薄片を観察して得 る以上の情報を抽出することを目指して，画像分光顕微鏡 を使った観測技術開発を進めている。地質学者や鉱物学 者が,岩石組織や鉱物組織を見ぬまま鉱物や岩石の研究を
する困難さは，本誌読者には容易に想像できるであろう。 無人探査で岩石切断面の組織が観察できるようになれば， 地質学者や鉱物学者は,サンプルリターン計画の実現まで 傍観を余儀なくされることなく,無人探査の段階から容易 に参入できるようになる。光して, 固体惑星 , 小惑星 , 惑 星の固体衛星へと, 鉱物·岩石組織研究の領域力゙近い将来 に一気に広がることを期待している。

謝 辞 本稿は，2003 年 11 月 1 3 日, 東京・八王子 で行われた YMO鉱物科学秋の学校での講演原稿を元に杂隹 誌用に再構成したものである。講演の場を与えてくだ さった三宅 亮博士, 富岡尚敬博士, 糀谷 浩博士, 宮島 延吉博士 ,本誌への投稿機会を与えてくださった本誌編集 委員会, 光して, 本稿を改善する有益な助言を下さった木 村 眞博士と匿名の査読者の方,担当編集委員の松原 聰 博士に感謝申し上げます。

\section{引用文献}

Barrat, J.A., Blichert-Toft, J., Gillet, Ph. and Keller, F. (2000): The differentiation of eucrites: The role of in situ crystallization. Meteorit. Planet. Sci., 35, 1087-1100.

Boesenberg, J.S., Prinz, M., Weisberg, M.K., Davis, A.M., Clayton, R.N., Mayeda, T.K. and Wasson, J.T. (1995): Pyroxene pallasites: A new pallasite grouplet (abstract). Meteoritics, 30, 488-489.

Buseck, P.R. (1977): Pallasite meteorites-Mineralogy, petrology, and geochemistry. Geochim. Cosmochim. Acta, 41, 711- 740 .

Buseck, P.R. and Goldstein, J.I. (1969): Olivine compositions and cooling rates of pallasitic meteorites. Bull.Geol. Soc.Amer., 80, $2141-2158$.

Coble, R.L. (1963): A model for boundary diffusion controlled creep in polycrystalline materials. J. Appl. Phys., 34, 16791682.

Greenberg, R. and Chapman, C.R. (1984): Asteroids and meteorites: Origin of stony-iron meteorites at mantle-core boundaries. Icarus, 57, 267-279.

Grove, T.L. (1978): Experimentally determined $\mathrm{FeO}-\mathrm{MgO}-\mathrm{CaO}$ partitioning between pyroxene and liquid in lunar basalts (abstract). EOS, 59, 401 .

Herring, C. (1950): Diffusional viscosity of a polycrystalline solid. J. Appl. Phys., 21, 437-445.

井出典孝, 横川美和, 佐伯和人 (1999): 曲率によるリップル 形態の解析: 複合流リップルの例. 堆積学研究 , 49, 4148.

Longhi, J. and Pan, V. (1988): Phase equilibrium constraints on the Howardite-Eucrite- Diogenite association. Proc. Lunar Planet. Sci. Conf. 18th, 459-470.

Miyamoto, M. (1997): Chemical zoning of olivine in several pallasites. J. Geophys. Res., 102, 21613-21618.

Miyamoto, M. and Takeda, H. (1993): Rapid cooling of pallasite: Comparison of chemical zoning with primitive achondrites (abstract). Meteoritics, 28, 404 - 405.

Miyamoto, M. and Takeda, H. (1996): Chemical zoning of olivine in several pallasites suggestive of faster cooling (abstract). Lunar Planet. Sci. Conf., 25, 921-922.

Narayan, C. and Goldstein, J. I. (1985): A major revision of iron meteorites cooling rates-An experimental study of the 
growth of Widmanstatten pattern. Geochim. Cosmochim. Acta, 49, 397-410.

Nishikawa, O., Saiki, K. and Wenk, H. (2004): Intra-granular strains and grain boundary morphologies of dynamically recrystallized quartz aggregates in a mylonite. J. Struct. Geol., 26, 127-141.

Saiki, K. (1997): Morphology and simulation of solid state rounding process. Geophys. Res. Lett., 24, 1519-1522.

Saiki, K., Laporte, D., Vielzeuf, D., Nakashima, S. and Boivin, P. (2003): Morphological analysis of olivine grains annealed in an iron-nickel matrix: Experimental constraints on the origin of pallasites and on the thermal history of their parent bodies. Meteorit. Planet. Sci., 38, 427-444.

Saiki, K. and Takeda, H. (1999): Origin of polymict breccias on asteroids deduced form their pyroxene fragments. Meteorit. Planet. Sci., 34, 271-283.

Saiki, K., Takeda, H. and Ishii, T. (2001): Mineralogy of Yamato-791192, HED breccia and relationship between cumulate eucrites and ordinary eucreites. Antarct. Meteorite Res., 14, $28-46$.

Scott, E.R.D. (1977a): Pallasites-Metal composition, classification, and relationships with iron meteorites. Geochim. Cosmochim. Acta, 41, 349-360.

Scott, E.R.D. (1977b): Formation of olivine-metal textures in pallasite meteorites. Geochim. Cosmochim. Acta, 41, $693-710$

Solomon, S.C. (1979): Formation, history and energetics of cores in the terrestrial planets. Phys. Earth Planet. Inter., 19, 168 182.

Stolper, E. (1977): Experimental petrology of eucritic meteorites. Geochim. Cosmochim. Acta, 41, 587-611.
Takahashi, E. (1983), Melting of a Yamato L3 chondrite (Y74191) up to 30 kbar. Proc. 8th Symp.Antarct. Meteorites, 168-180.

Taylor, G.J., Maggiore, P., Scott, E.R.D., Rubin, A.E. and Keil, K. (1987): Original structures and fragmentation and reassembly histories of asteroids: Evidence from meteorites. Icarus, 69, 1 - 13 .

Treiman, A.H. (1997): The parent magmas of the cumulate eucrites: A mass balance approach. Meteorit. Planet. Sci., 32, 217-230.

Ulff-Møller, F., Choi, B.G., Rubin, A.E., Tran, J. and Wasson, J.T. (1998): Paucity of sulfide in a large slab of Esquel: New perspectives on pallasite formation. Meteorit. Planet. Sci., 33, 221-227.

Wasson, J.T., Lange, D.E., Francis, C.A. and Ulff-Møller, F. (1999): Massive chromite in the Brenham pallasite and the fractionation of $\mathrm{Cr}$ during the crystallization of asteroidal cores. Geochim. Cosmochim. Acta, 63, 1219-1232.

Wetherill, G.W. (1989): The Formation and Evolution of Planetary Systems, Formation of the solar system: consensus, alternatives and missing factors. pp. 356, Cambridge Univ. Press, Cambridge.

Wood, J.A. (1978): Nature and evolution of the meteorite parent bodies: Evidence from petrology and metallurgy. In Asteroids: An exploration assessment (Morisson D. and Wells W.C., Eds.). NASA Conf. Pub., 2053, 45-57.

Yang, C.W., Williams, D.B., and Goldstein, J.I. (1997): A new empirical cooling rate indicator for meteorites based on the size of the cloudy zone of the metallic phases. Meteorit. Planet. Sci., 32, 423-429. 